\title{
Characterization Of Coal Quality Based On Ash Content From M2 Coal-Seam Group, Muara Enim Formation, South Sumatra Basin
}

\author{
Frillia Nasution ${ }^{1 *}$, Stevanus Nalendra ${ }^{1}$ \\ ${ }^{1}$ Geology Study Program, Engineering Faculty, Sriwijaya University.
}

* Corresponding Author: nasutionfrillia@gmail.com

Tel.: +62-852-7329-9464;

Received: May 22, 2017. Revised : July 5, 2016, Accepted: Aug 5, 2017, Published: 1 Sept 2016

DOI : 10.24273/jgeet.2017.2.3.292

\section{Abstract}

Muara Enim Formation is well known as coal-bearing formation in South Sumatra Basin. As coal-bearing formation, this formation was subjects of many integrated study. Muara Enim Formation can be divided into four coal-seam group, M1, M2, M3, and M4. The M2 group comprising of Petai (C), Suban (B), Lower Mangus (A2), and Upper Mangus (A1). Depositional environments of Group M2 is transitional lower delta plain with sub-depositional are crevasse splay and distributary channel. The differentiation of both sub-depositional environments can be caused the quality of coal deposit. One of quality aspects is ash content. This research conducted hopefully can give better understanding of relationship between depositional environments to ash content. Group M2 on research area were found only Seam C, Seam B, and Seam A2, that has distribution from north to central so long as $1400 \mathrm{~m}$. Coal-seam thickness $C$ ranged between 3.25-9.25 m, Seam B range 7.54$13.43 \mathrm{~m}$, and Seam C range 1.53-8.37 m, where all of coal-seams thickening on the central part and thinningsplitting to northern part and southern part. The ash content is formed from burning coal residue material. Ash contents on coal seam caused by organic and inorganic compound which resulted from mixing modified material on surrounded when transportation, sedimentation, and coalification process. There are 27 sample, consists of 9 sample from Seam C, 8 sample from Seam B, and 10 sample from Seam A2. Space grid of sampling is 100-150 m. Ash content influenced by many factors, but in research area, main factor is existence of inorganic parting. Average ash content of Seam C is 6,04\% Seam B is 5,05\% and Seam A2 is 3,8\% Low ash content influenced by settle environment with minor detrital material. High ash content caused by oxidation and erosional process when coalification process. Ash content on coal in research area originated from detritus material carried by channel system into brackish area or originated from higher plant in brackish area. The high ash content also can be caused by after the coal deposited. It had originated from overburden horizon which infill in cleat of coal seam.

Keywords: Muara Enim Formation, Group M2, Transitional Lower Delta Plain, Ash Content.

\section{Introduction}

\subsection{Background}

Muara Enim Formation is well known as coalbearing formation in South Sumatra basin. As coalbearing formation, this formation was subjects of many integrated study, such as sedimentology, depositional environment, paleogeography, structure geology, tectonic evolution, depositional history, and many more (De Coster, 1974).

Muara Enim Formation consists of sandstone, claystone and coal. Coal in bottom part of Middle Palembang formation in southern part of this basin often used as stratigraphy marker. Muara Enim formation can be divided into four coal-seam group, M1, M2, M3, and M4. (De Coster, 1974) interpreted this formation deposited in Late Miocene-Pliocene.
The $M 2$ group is comprising of Petai (C), Suban (B), Lower Manggus (A2), and Upper Manggus (A1). Group M2 consists of intercalated of claystonesandy claystone, fine-medium sand, coal in bottom part. Coal seams in Group M2 have limited distribution. It caused by depositional environment from this unit. Depositional environment of Group M2 is transitional lower delta plain with subdepositional are crevasse splay and distributary channel.

The differentiation of both sub-depositional environments can be caused the quality of coal deposit. One of quality aspects is ash content. This research conducted hopefully can give better understanding of relationship betw een depositional environments to ash content. 


\subsection{Description of the Research Area}

The work is conducted in the Bukit Kendi coalfield that has been mined since 1996, and nowadays the mine concessions is under the management of the state-owned company of Baramulti Group. In recent times, the area becomes a mining area, this can have a positive impact on research because it can find outcrops such as on the mine wall, on the cliffs of hauling roads, and some rivers.

The region is administratively included within Pullo Panggung District, Tanjung Lalan District, and Sleman District of Muara Enim Regency of South Sumatra Province. Geographycally, Muara Enim located on between $4^{0}-6^{\circ}$ LS and $104^{\circ}-106^{\circ}$ BT (Fig. 1). Research area can be accessed using light vehicle for five hours from Palembang City.

The purpose of this research is to identified coal quality in Pullo Panggung area, and objectives of this research is to mapping the coal distribution based on ash content.

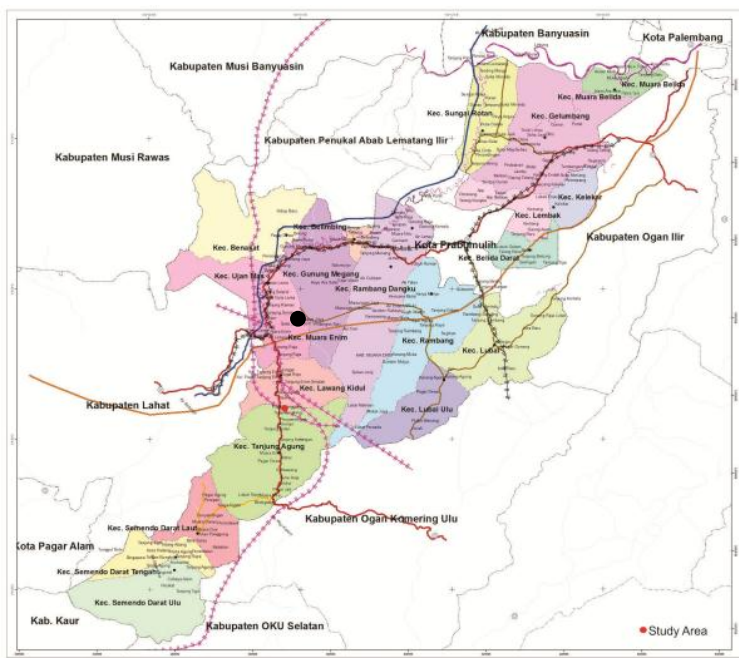

Fig. 1. Research area (Pemerintah Kabupaten Muara Enim, 2012).

\section{An Overview of Geology}

\subsection{Tectonic Framework}

South Sumatra Basin formed in Early Tertiary (Eocene-Oligocene) when graben series develops as oblique subduction system between Hindia Oceanic Plate beneath Asian Continental Plate (De Coster, 1974). There are three orogeny episode which formed structure framework of South Sumatra Basin, they are Middle Mesozoikum orogeny, Late Cretaceous-Early Tertiary and Plio-Pleistosen orogeny (De Coster, 1974),.

First episode, Paleozoikum and Mesozoikum metamorphosed deposit, folded and faulted into structural boudine and intrusion by granite batholith and also formed basement structural style. (Pulunggono et al., 1992), this phase formed transform fault with NW-SE trend (Fig. 2).

Second episode, in Late Cretaceous there are extensional phase which resulted tensional movement and formed graben and horst with N-S dominant trend. Combined with Mesozoikum orogeny and Pre-Tertiary weathered rocks, those tensional movement formed old structure which controlled Pre-Talang Akar formation development.

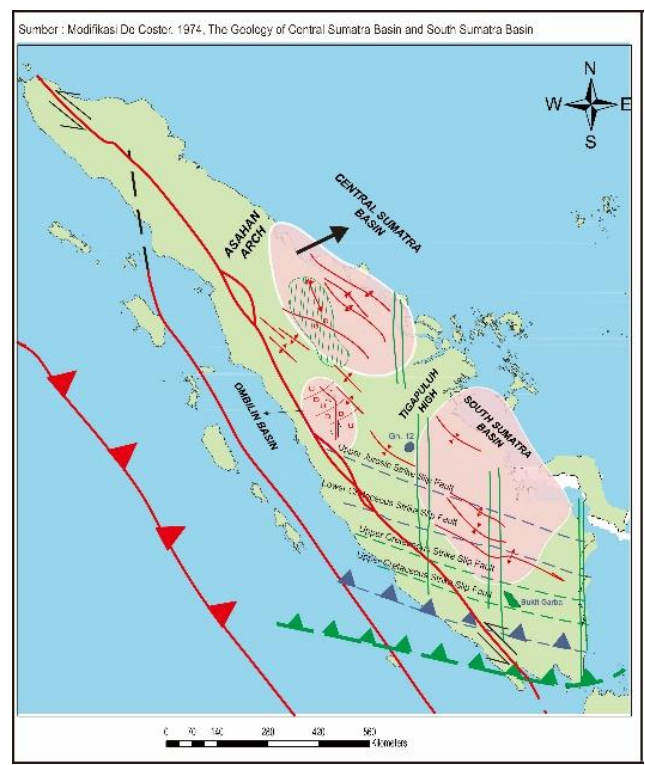

Fig. 2. South Sumatra tectonic framework (Pulunggono et al., 1992).

Third episode are compressional phase in PlioPleistocene which caused depositional pattern changed to regression and influenced to formed recent fold and fault structural style. On this tectonic period, there also uplifted of Bukit Barisan Mountains which resulted Semangko strike-slip fault along Bukit Barisan Mountains. Horizontal movement began from Early Pleistocene until now which influence the South Sumatra Basin and Central Sumatra Basin condition. This condition caused newly faults have development trend parallel with Semangko faults. Due to this horizontal movement, orogeny in Plio-Pleistocene resulted folds with NW-SE but the faults have NE$\mathrm{SW}$ oriented. Faults which formed in this basin are thrust fault, strike-slip, and normal fault. Dominant structures are structures with NW-SE trend which resulted from Plio-Pleistocene orogeny. As patterns, structures can be divided into old pattern with N-S oriented and younger pattern with NW-SE trend which parallel with Sumatra trend.

\subsection{Physiography}

Physiographically, (Bemmelen, 1949), divided Sumatra into six physiography zone (Fig. 3). They are a) Barisan range, b) Semangko zone, c) Tigapuluh mountains zone, d) Outer island arc zone, e) Sunda shelf, and f) Lowland and undulating zone.

Based on (Bemmelen, 1949) classification, research area located on lowlands and undulating zone (orange square).

\subsection{Regional Stratigraphy}

Regional stratigraphy of South Sumatra Basin well known as megacycle which consists of transgression and followed by regression phase (Adiwidjaja and de Coster, 1973). Formations 
deposited on transgression phase are Telisa Group (Talang Akar Fm., Baturaja Fm., and Gumai Fm.). On other side, regression phase deposited Palembang Group (Air Benakat Fm., Muara Enim Fm., and Kasai Fm. Older formations (Lemat Fm. and Older Lemat Fm. deposited before main transgression phase. Stratigraphy unit of South Sumatra Basin from oldest to youngest (De Coster, 1974), are PreTertiary Group, Kikim Fm., Older Lemat Fm., Lemat Muda Fm., Talang Akar Fm., Baturaja Fm., Telisa Fm., Gumai Fm., Lower Palembang Fm., Middle Palembang Fm., and Upper Palembang Fm. (Fig. 4).

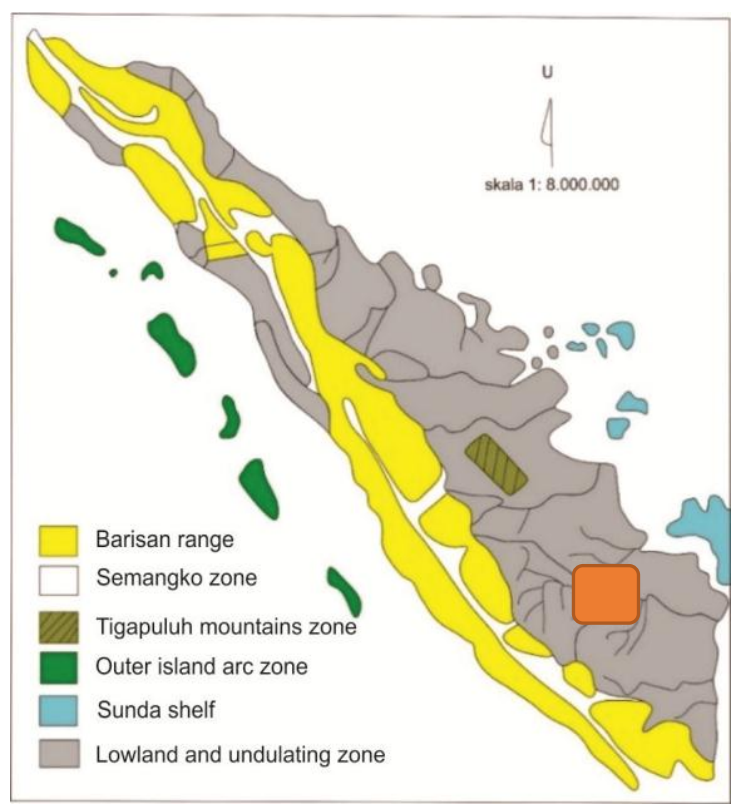

Fig. 3. Physiography zone of Sumatra (Bemmelen, 1949).

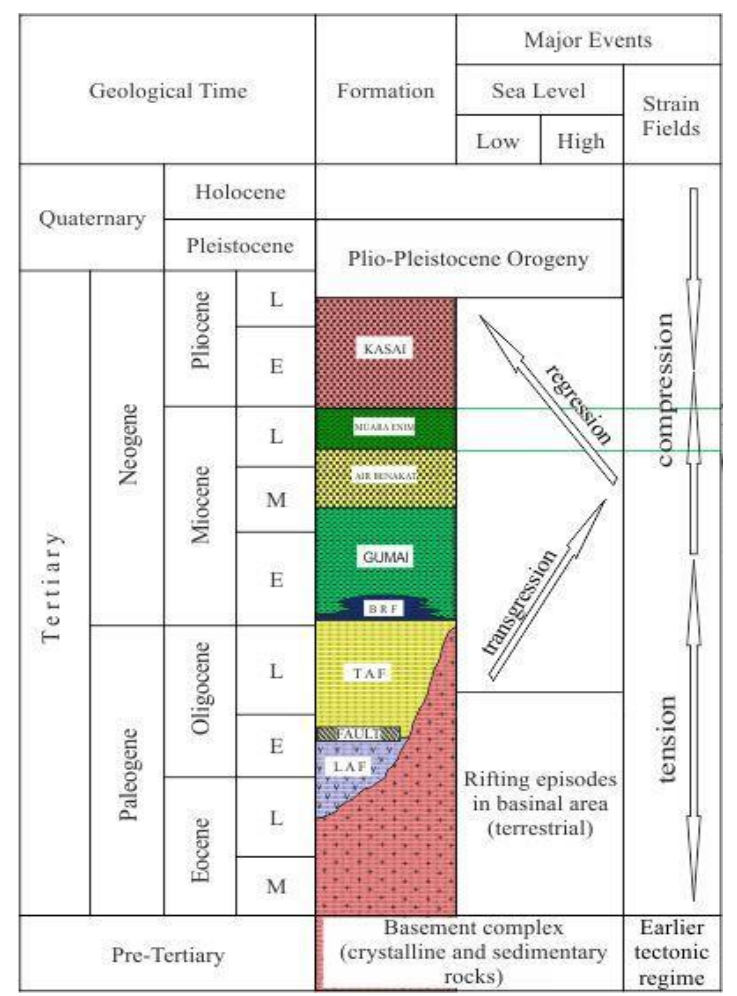

Fig. 4. Regional stratigraphy of South Sumatra Basin (Sutriyono et al., 2016).
Muara Enim Formation is coal-bearing formation in South Sumatra Basin. Muara Enim Formation can divided into four coal-seam group (Ilyas, 1999), accordingly from bottom to top are M1, M2, M3, and M4 (Fig. 5). The M2 group have found in research area. Group M2 contains majority of coal resources in Tanjung Enim area. The M2 consists of three major coal unit (from top to bottom); Mangus, Suban and Petai (Amier, 1991). Recognized these unit locally split into two seams as follows: Mangus unit ( $A 1$ and $A 2$ seams), Suban unit (B1 and B2 seams), and Petai unit ( $\mathrm{Cl}$ and $\mathrm{C} 2$ seams)

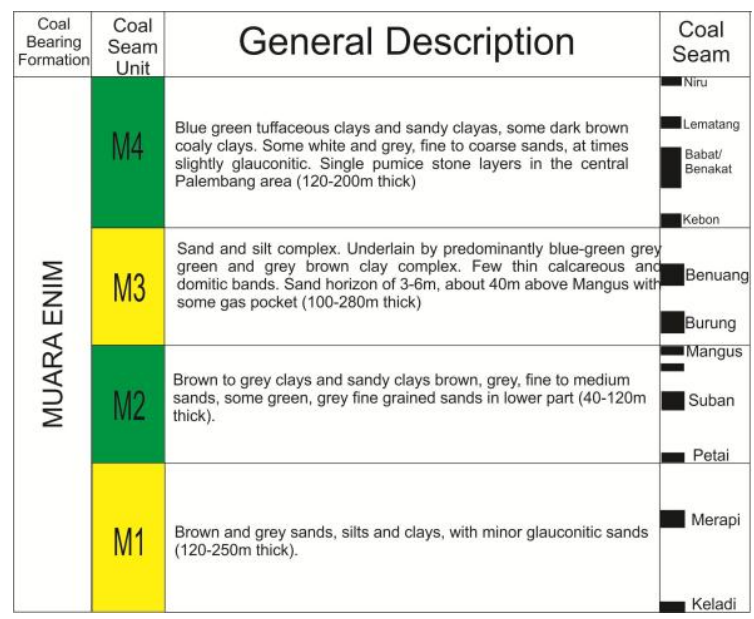

Fig. 5. Stratigraphy of Muara Enim Formation (modified (A.D.Tarsis, n.d.)).

Pulunggono, 1986 interpreted Muara Enim formation deposited in shallow marine to parallic and non-marine environments. This formation consists of claystones and shales intercalated by sandstone and coal layer.

On other hand, based on analysis of well and seismic data, divided Muara Enim formation into two depositional packages: Lower and Upper Muara Enim formation (Muksin et al., 2012),. These two depositional packages consists of three subenvironment, they are tidal mud flat, tidal mixed flat and tidal sand flat environment.

\section{Research Method}

Research method was conducted on this study are:

- Field observation, including observation of relationship coal layer to other layers (bottom and top) and also the condition which influenced the layers.

- Quality analysis of coal layer to identified distribution of coal layer and geology factors.

- Research were conducted by reconnaissance through study literature and field observation, analyses phase (primary analysis and secondary analysis), and conclusion phase (result).

Group M2 on research area were found only Seam C, Seam B, and Seam A2, that has distribution from north to central so long as 1400 m (Fig. 6). 
Coal-seam thickness C ranged between 3.25-9.25 m, Seam B range 7.54-13.43 m, and Seam Crange 1.53$8.37 \mathrm{~m}$, where all of coal-seams thickening on the central part and thinning-splitting to northern part and southern part.

The ash content is formed from burning coal residue material. Ash contents on coal seam caused by organic and inorganic compound which resulted from mixing modified material on surrounded when transportation, sedimentation, and coalification process. There are 27 sample, consists of 9 sample from Seam C (Table 1), 8 sample from Seam B (Table 2), and 10 sample from Seam A2 (Table 3). Space grid of sampling is $100-150 \mathrm{~m}$. The coal quality analysis discussed throughout this research were analyzed on air dried basis (adb.).

Table 1. Ash value of seam C.

\begin{tabular}{ccc}
\hline Sample Code & Seam & Ash Value (adb) \\
\hline FR-11 & C & 4.66 \\
FR-15 & C & 8,13 \\
FR-12 & C & 6 \\
FR-16 & C & 7,45 \\
FR-17 & C & 7 \\
FR-10 & C & 4,73 \\
FR-05 & C & 5,59 \\
FR-14 & C & 7,24 \\
FR-07 & C & 2,23 \\
\hline
\end{tabular}

Tabel 2. Ash Value of Seam B.

\begin{tabular}{ccc}
\hline Sample Code & Seam & Ash Value (adb) \\
\hline FR-01 & B & 5,63 \\
FR-08 & B & 8,04 \\
FR-02 & B & 5,61 \\
FR-12 & B & 6,4 \\
FR-10 & B & 3,07 \\
FR-05 & B & 4,95 \\
FR-14 & B & 3,69 \\
FR-07 & B & 3,05 \\
\hline
\end{tabular}

Table 3. Ash Value of Seam A2.

\begin{tabular}{ccc}
\hline Sample Code & Seam & Ash Value (adb) \\
\hline FR-01 & A2 & 3,03 \\
FR-08 & A2 & 1,71 \\
FR-02 & A2 & 2,48 \\
FR-03 & A2 & 3,39 \\
FR-09 & A2 & 2,59 \\
FR-04 & A2 & 3,28 \\
FR-10 & A2 & 3,24 \\
FR-05 & A2 & 2,71 \\
FR-07 & A2 & 6,85 \\
FR-06 & A2 & 9,56 \\
\hline
\end{tabular}

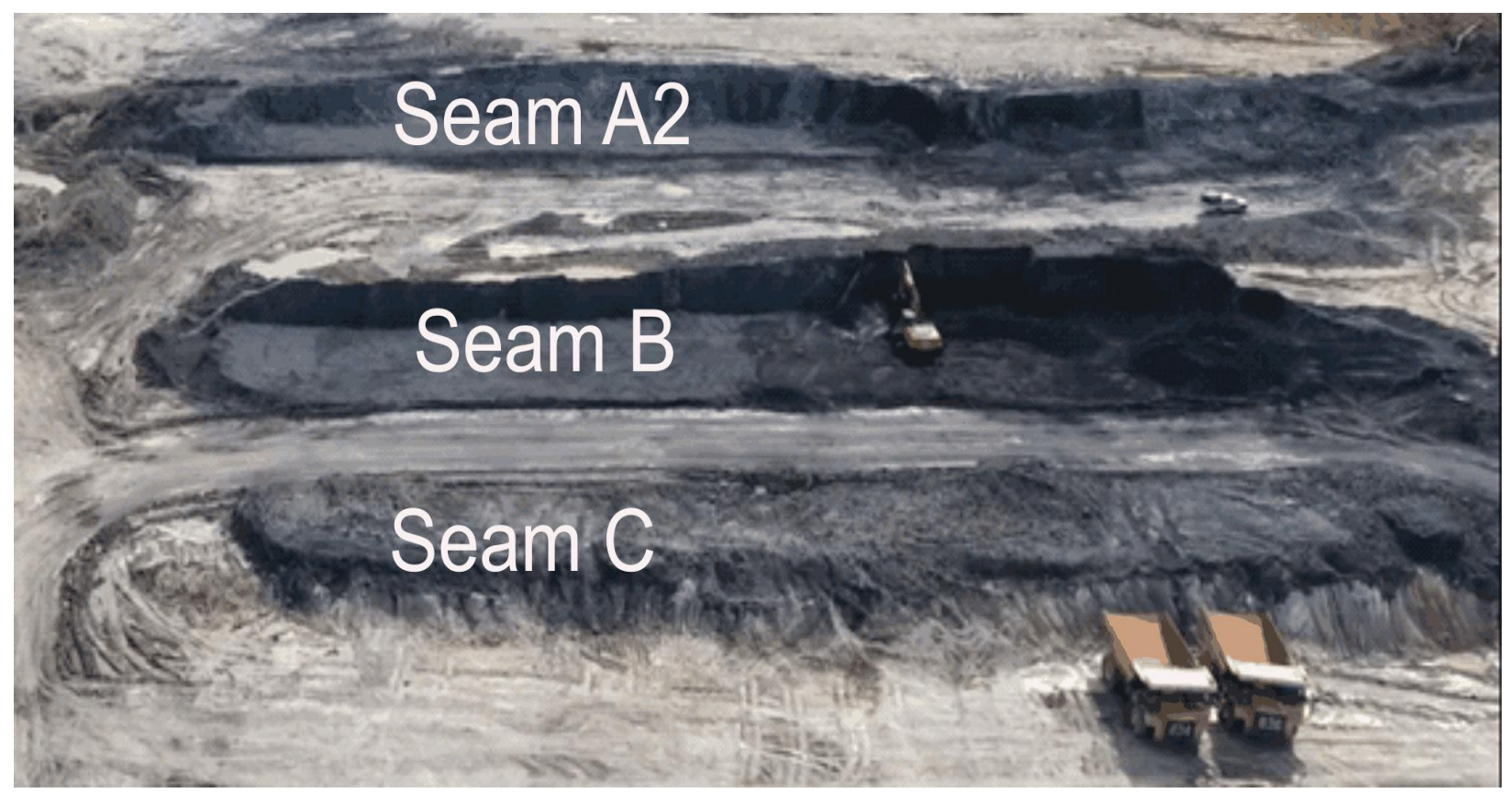

Fig. 6. Outcrops of seam A2, seam B, and seam C. 


\section{Result and Discussion}

The ash contents for all samples varies slightly, with average ranging from 1.71-9.56 adb.\%

\subsection{Ash content analysis of Seam C}

Seam $C$ on research area have thickness around 3.25-9.25 $\mathrm{m}$, where divided into 5 body with 4 parting with various thickness between $5-30 \mathrm{~cm}$. Stratigraphic profile of Seam C can be seen on Fig. 7 .
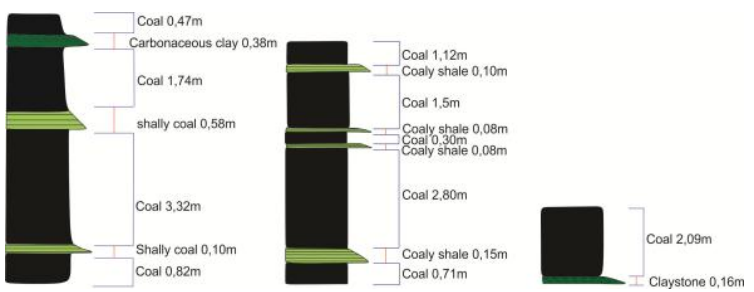

Fig. 7. Coal profile of coal-seam Cin northern (left), central (middle), and southern (right) of research area.

Based on ash content on Seam C (Fig. 8), showed highest ash content located on central part of research area, besides that northern and southern part have low ash content. It can be caused by northern and southern part are depocenter of basinal area. This condition made coal layer on this part have thick layer and less of parting. The highest ash content located on central part of research area, it indicated that coal deposited in edge of basinal area. This part could influenced by terrestrial material. This condition indicated why ash content on edge of basinal have ash content higher than depocenter of basinal area.

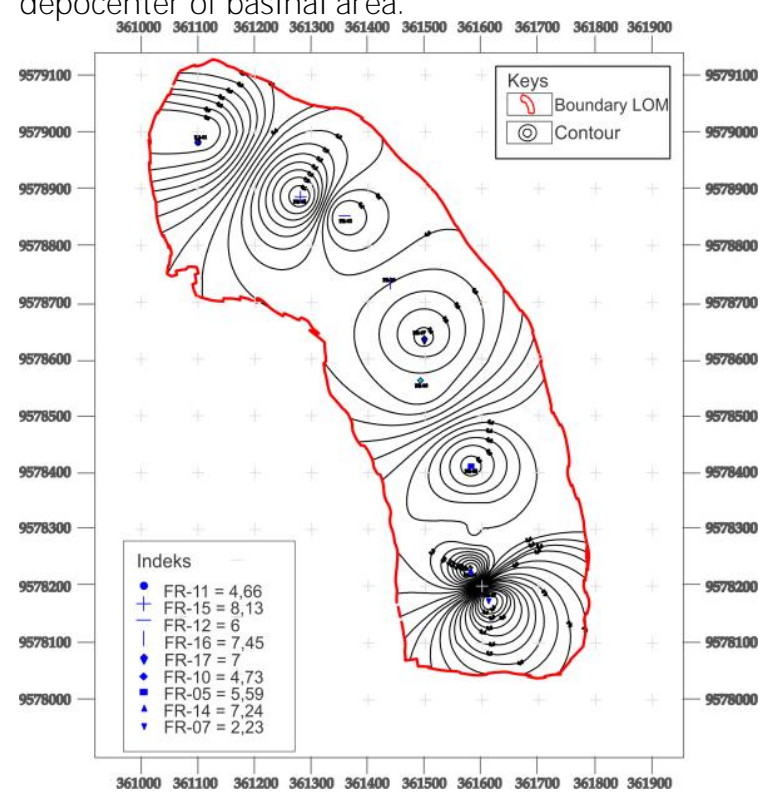

Fig. 8. Iso ash map of Seam C.

\subsection{Ash content analysis of Seam B}

Seam B on research area have thickness around 7.54-13.43 $\mathrm{m}$, where divided into 5 body with 4 parting with various thickness between $4-20 \mathrm{~cm}$. Stratigraphic profile of Seam C can be seen on Fig. 9.

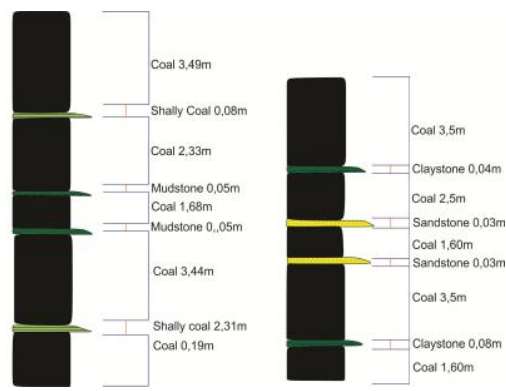

Fig. 9. Coal profile of coal-seam B in northern (left), central (middle), and southern (right) of research area.

Based on ash content on seam B (Fig. 10), showed ash content increased to northern part. That analysis indicated that coal seam B in northern part deposited in edge of basinal area. This part could influenced by terrestrial material. This condition indicated why ash content on edge of basinal have ash content higher than depocenter of basinal area.

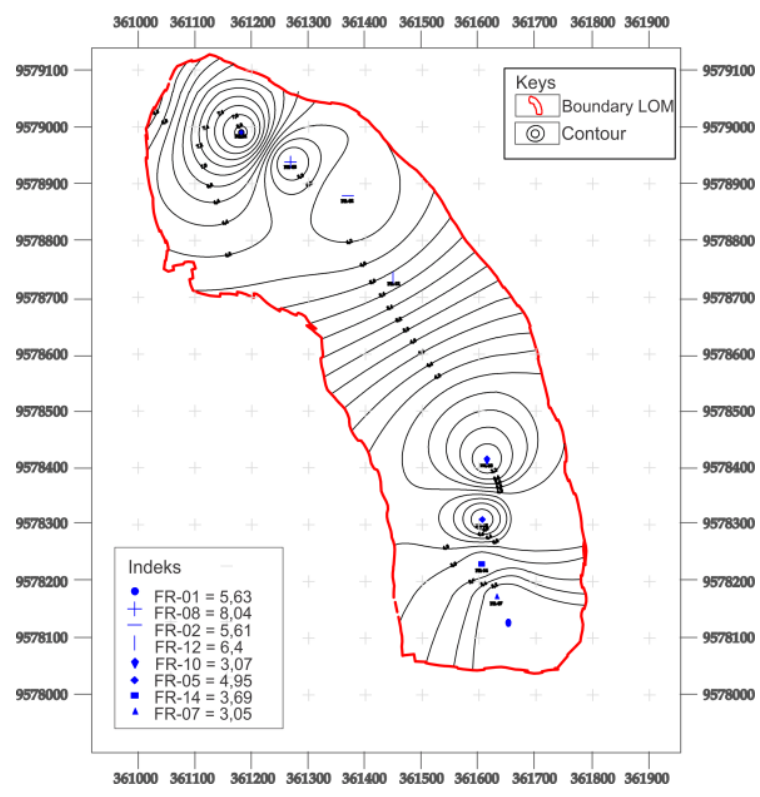

Fig. 10. Iso ash map of Seam B.

\subsection{Ash content analysis of Seam A2}

Seam A2 on research area have thickness around 1.53-8.37 $\mathrm{m}$, where divided into 3 body with 2 parting with various thickness between $5-10 \mathrm{~cm}$. Stratigraphic profile of Seam C can be seen on Fig. 11.

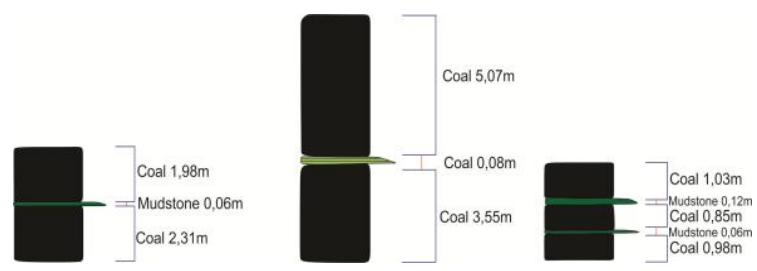

Fig. 11. Coal profile of coal-seam A2 in northern (left), central (middle), and southern (right) of research area. 
Based on ash content of seam A2 (Fig. 12), showed ash content increased to southern part. It caused by southern part is edge of basinal area. Coal which deposited in edge of basinal area mainly influenced with terrestrial material. It resulted coal in this area have higher ash content than central part. The low ash content in central part was assumed that minor terrestrial content. It indicated the area is depocenter of basinal area.

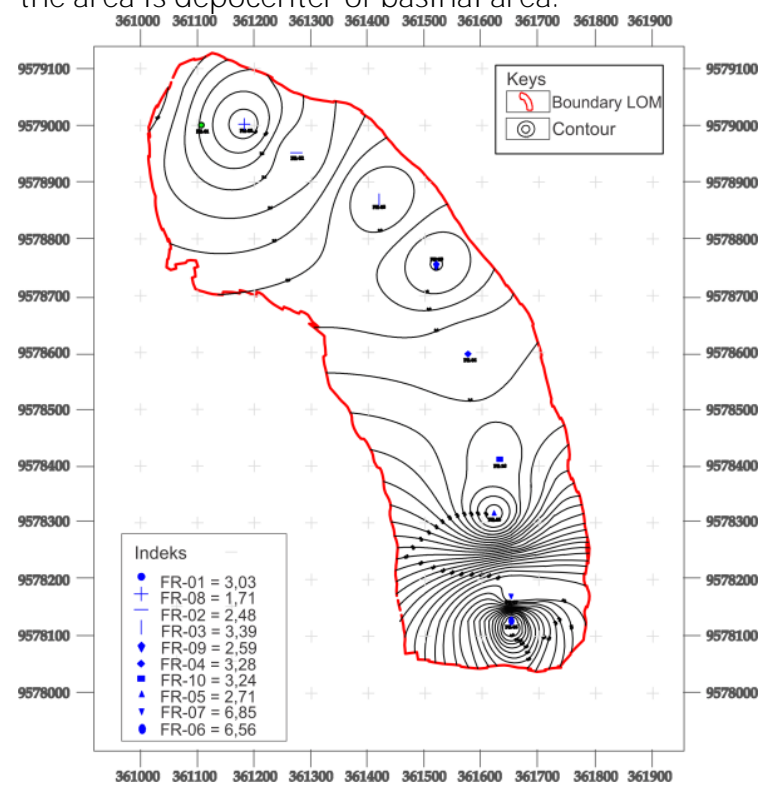

Fig 12. Iso ash map of Seam A2.

\subsection{Interpretation of depositional environment}

Depositional environment of Group M2 in research area is transitional lower delta plain by using horne, 1978 classification of depositional environment based on coal characteristic. It indicated by lithology changed and repeated lithology as characteristics of depositional processes influenced by tidal (Thomas, 2013) (Fig. 13).

Parting occurence on coal seam in research area caused by in depositional processes of coal there are flooding phase or formed by tidal process which caused fine grain sediment also deposited coincided with coalification process. But fine grain sediment was not continuous deposited because the limited source of this material. The depositional process still occupied to deposit peat material and coalification process. This process can be caused occurrence of parting in coal seam.

Ash content on coal seam in research area originated from detritus material which brought by channel system into brackish area or originated from higher plant in brackish area. The high ash content also can be caused by after the coal deposited. It can origin from overburden horizon which infill in cleat of coal layer.

In research area, coal seam have found with various thickness (thick and thin). It influenced by two processes: process when depositional takes place and process after deposited. First process is basin subsidence, if there are rapid subsidence it could made thick coal seam. Second process is erosional process by channel changing. It could be caused thinning on edge of coal seam. On other hand, various coal thickness can also influence by different of rate of peat growth. If rapid peat growth rate, it caused thick coal layer, but if slow peat growth rate, it caused thin coal seam.

\section{Conclusion}

Coal-seam group of Muara Enim Formation in research area occurred on Group M2 unit which consists of Seam C, Seam B, and Seam A2. Group M2 have various thickness. Thickness of Seam $A 2$ is around 1.53-8.37 m. Seam B between 7.54-13.43 m, and Seam $C$ have thickness is 3.25-9.25 m. All of seam have thickening geometry in central part and thinning in both of edge part (northern and southern part).

Based on sedimentation characteristic, Group M2 in research area deposited in transitional lower delta plain with sequence interburden characteristics, intercalated of fine-coarse grain with fining upwards and coarsening upwards, thick coal seam with continuous distribution.

Ash content influenced by many factors, but in research area, main factor is existence of parting. Average ash content of Seam C is $6.04 \mathrm{adb} \%$ Seam $B$ is 5.05 adb.\% and seam A2 is 3.8 adb.\% Low ash content influenced by settle environment with minor detrital material. High ash content caused by oxidation and erosional process coincided with coalification process.

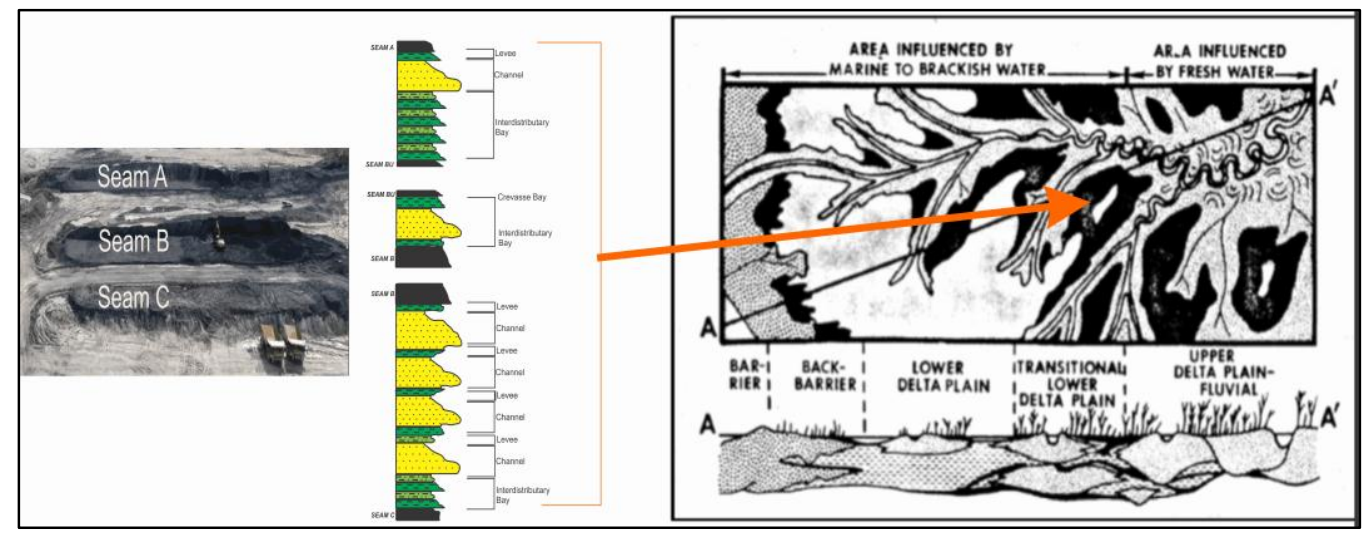

Fig. 13. Measuring section model compared to depositional environment of Group M2. 


\section{Acknowledgements}

This research was funded by the Sriwijaya University undergraduate Geology study program. The authors would like to gratefully acknowledge PT. Prima Mulia Sarana Sejahtera (Baramulti Group) for the support during field session and for providing some coal analysis.

\section{References}

A.D.Tarsis, n.d. Penyelidikan Batubara Bersistem Dalam Cekungan Sumatera Selatan Di Daerah Benakat Minyak Dan Sekitarnya, Kabupaten Muara Eim Propinsi Sumatera Selatan. Jakarta.

Adiwidjaja, P., de Coster, G.L., 1973. Pre-Tertiary paleotopography and related sedimentation in South Sumatra. Proc. Indones. Pet. Assoc. 89-104.

Amier, R.l., 1991. Coals, source rocks and hydrocarbons in the South Palembang sub-basin, south Sumatra, Indonesia.

Bemmelen, van, 1949. Geology of Indonesia, Vol. IA. ed. Goverment Printing Office, The Hague

De Coster, G.L., 1974. The Geology of the Central and South Sumatra Basins. Proc. Indones. Pet. Assoc. Third Annu. Conv. June 1974 77-110.

Horne, J.., Ferm, J.., Caruccio, F.., Baganz, P., 1978. Depositional Models in Coal Exploration and Mine Planning in Appalachian Region. Am. Assoc. Pet. Geol. Bull. 62, 2379-2411.

Ilyas, S., 1999. Pengkajian Cekungan Btubara Di Daerah Talang Ubi, Kabupaten Musi Banyuasin dan Muara Enim, Provinsi Sumatera Selatan. Pemaparan Has. Kegiat. Lapangan DIK-S Batubara, DSM 1-6.

Muksin, N., Yusmen, D., Waren, R., Werdaya, A., Djuhaeni, D., 2012. Regional Depositional Environment Mode of Muara Enim Formation and Its Significant Implication for CBM Prospectivity in South Sumatra Basin , Indonesia * 80272

Pemerintah Kabupaten Muara Enim, 2012. Peta Administrasi Wilayah Kabupaten Muara Enim.

Pulunggono, A., 1986. Tertiary Structural Features Related To Extensional and Compressive Tectonics in The Palembang Basin, South Sumatra. Proc. Indones. Pet. Assoc.

Pulunggono, A., S. Haryo, A., Kosuma, C.G., 1992. PreTertiary and Tertiary Fault Systems as a Framew ork of the South Sumatra Basin; A Study of SAR-Maps. Proc. Indones. Pet. Assoc. 21, 92-11.37.

Sutriyono, E., Wiwik, E., Hastuti, D., Susilo, B.K., 2016. Geochemical Assessment of Late Paleogene Synrift Source Rocks in The South Sumatera Basin. Int. J. GEOMATE 11, 2208-2215.

Thomas, L., 2013. Coal Geology, Second Edi. ed, Coal Geology. A John Wiley \& Sons, Ltd., doi: $10.1002 / 9781118385685$ 